\title{
CECÍLIA MEIRELES E A TRAVEL IN BRAZIL: duas festividades religiosas no Rio de Janeiro - Santo Antônio e Nossa Senhora da Penha
}

\author{
Luis Antonio Contatori Romano \\ (Unifesspa/CNPq) \\ https://orcid.org/0000-0003-2646-5909
}

\section{RESUMO}

Pretende-se analisar dois artigos ilustrados, que foram publicados na revista Travel in Brazil (1941-1942), editada por Cecília Meireles: "Um Coronel muito estranho" e "Penha". Ambos tratam da divulgação turística de festividades religiosas no Rio de Janeiro para o público norte-americano, no contexto do Estado Novo brasileiro. Os objetivos da análise são verificar a autoria dos artigos a partir do estilo de escrita, comparar as versões de lendas religiosas que eles relatam com as de outras fontes, discutir a que tipo de turista ou viajante eles se destinavam e relacionar as imagens fotográficas com os textos verbais no contexto da ideologia modernizadora do Governo Vargas.

PALAVRAS-CHAVE: Turismo religioso; Governo Vargas; Revista Travel in Brazil; Cecília Meireles. 


\section{CECÍLIA MEIRELES AND TRAVEL IN BRAZIL: two religious festivities in Rio de Janeiro - Santo Antônio and Nossa Senhora da Penha}

\section{ABSTRACT}

This paper intends to analyze two illustrated articles, published in the magazine Travel in Brazil (1941-1942), edited by Cecília Meireles: "A very strange Colonel" and "Penha". Both deal with the publicizing of religious festivities in Rio de Janeiro to the North-American public, in the context of the Brazilian "Estado Novo". The aims of the analysis are to verify the authorship of the articles on the basis of their writing style, to compare the versions of religious legends they report with those from other sources, to discuss what kind of tourist or traveler they targeted and to relate the photographic images to the verbal texts in the context of the modernizing ideology of the Vargas Government.

KEYWORDS: Religious tourism; Vargas Government; Travel in Brazil Magazine; Cecília Meireles.

\section{Introdução}

Na década de 1940 não somente o carnaval e as praias cariocas eram objetos de divulgação destinados ao olhar turístico estrangeiro, como também peregrinações religiosas, festejos que se seguiam a elas e lendas a que estavam relacionadas. Esses elementos da cultura popular foram apresentados por Cecília Meireles e por fotógrafos estrangeiros em textos ilustrados com sofisticado material fotográfico. Coube à revista Travel in Brazil, publicação em inglês do DIP (Departamento de Imprensa e Propaganda) do Estado Novo, destinada ao leitor norte-americano, essa iniciativa que aliava modernidade e tradição, familiarização turística/ urbanística e desfamiliarização cultural.

A Travel in Brazil circulou entre 1941 e 1942, Cecília Meireles era a editora. Além da poeta, nela colaboraram outros escritores ligados a correntes do Modernismo, como Mário de Andrade, Manuel Bandeira, Sérgio Buarque de Holanda, José Lins do Rego, Rachel de Queiroz, Menotti Del Picchia e Tasso da Silveira. Publicava-se ainda textos de autores 
estrangeiros, entre os quais Paulo Rónai, que emigrou para o Brasil como refugiado de guerra.

Este estudo se deterá na análise dos artigos "Um Coronel muito estranho" (Travel in Brazil, v. 1, no 2, 1941) e "Penha" (Travel in Brazil, v. 2, no 2, 1942), ambos de Meireles, que assina com o pseudônimo de Florência, ilustrados com fotografias do alemão Paul Stille e do francês Jean Manzon, respectivamente. Apresentar-se-á uma síntese sobre o moderno fotojornalismo no Brasil. Em seguida, serão analisados cada um dos textos. A partir da análise do estilo da escrita comparativamente a crônicas de viagem de Cecília Meireles, será possível confirmar a hipótese de que Florência é um pseudônimo de Meireles. Serão cotejadas também as versões de Meireles sobre as origens de cada uma das igrejas e das lendas religiosas a elas vinculadas: Convento de Santo Antônio e Basílica de Nossa Senhora da Penha, ambas no Rio de Janeiro, com a de outras fontes, como as divulgadas pelos sites das mesmas igrejas. A partir dessas diferenças, se poderá melhor compreender a concepção de turismo de Meireles e a imagem de leitor que projetava para os textos. Por fim, deter-se-á na análise de possíveis relações entre os textos verbais e o material fotográfico que os ilustra, procurando-se evidenciar o desejo de modernidade que as imagens sugerem.

\section{0 moderno fotojornalismo e a revista Travel in Brazil}

No decorrer da década de 1930, revistas ilustradas surgiram na Alemanha, de onde difundem influências para Inglaterra, Estados Unidos e outras partes do mundo. Concomitantemente à difusão dessas revistas, houve uma popularização da fotografia familiar na Europa Central durante a década de 1930, devido à produção de máquinas fotográficas de pequeno porte, como a Leica.

Uma nova geração de fotógrafos, muitos deles amadores, chega ao Brasil entre a segunda década do século XX e o fim da II Guerra Mundial, oriundos da Europa Central, "na condição de refugiados ou imigrantes que procuram escapar da crise econômica e da perseguição política ou racial" (LISSOVSKY, 2013, p. 31). Esses estrangeiros introduziram novos modos de fotografar, além dos tradicionais ângulos frontais, na altura do olho, ou "foto-umbigo", com a câmera à altura do estômago. Eles dão ori-

1 Publicado com o título "A Very Strange Colonel". 
gem ao novo fotojornalismo no Brasil, que tem seu marco com a revista $O$ Cruzeiro, autorreconhecida como contemporânea do arranha-céu, da era do rádio e da viagem aérea. $O$ Cruzeiro passa a contar com o trabalho do fotógrafo francês Jean Manzon, no início da década de 1940, em parceria com o colunista David Nasser, amalgamando assim texto e imagem, conforme o estilo do novo fotojornalismo.

Com o afluxo de fotógrafos estrangeiros que trazem novas técnicas e novos equipamentos, a fotografia também no Brasil passa a ser enfatizada como prática moderna, que "enaltece o veículo que faz dela sua estrela, transforma seus repórteres fotográficos em heróis e, finalmente, forma e educa seu público" (LISSOVSKY, 2013, p. 32). É esse caráter educativo da fotografia que é instrumentalizado pelo Estado Novo de Vargas, cabendo ao alemão Peter Lange a tarefa de ilustrar a Obra Getuliana, com a colaboração de outros estrangeiros, tais como Erich Hess e Paul Stille. Esse livro, coordenado pelo Ministro Gustavo Capanema, deveria ser comemorativo das realizações nos dez anos do Governo Vargas em 1940, mas não chegou a ser editado.

De acordo com Lacerda (1994), os fotógrafos que faziam trabalhos para o Estado Novo foram distribuídos pelos estados brasileiros, com o propósito de fotografarem as realizações de Vargas que associavam o Brasil à modernidade ou que registravam obras do patrimônio histórico e artístico nacional, reforçando vínculos com as tradições europeias. Conforme relata o alemão Hess em entrevista à pesquisadora Teresinha Marino, em 1983 (GRIECO, 2013), ele chegou ao Brasil em 1936, em 1937 passou a fotografar, como freelancer, para o SPHAN (Serviço do Patrimônio Histórico e Artístico Nacional), atual IPHAN, viajando por vários estados brasileiros. Em algumas dessas viagens, como a que realizou a Minas Gerais em 1938, acompanhava o Diretor do SPHAN, Rodrigo F. M. de Andrade.

Em conexão com a política de modernização do Brasil durante o Estado Novo, a revista Travel in Brazil, vinculada à Divisão de Turismo do DIP, podia dispor de material autoral de fotógrafos europeus que emigraram para o Brasil nos anos de 1930 e 1940, entre os quais Lange, Hess, Preising, Stille, Manzon, com os quais ilustrava seus textos sobre turismo. Raúl Antelo (2004, p. 17-18) considera que vários periódicos culturais na era Vargas pautavam-se "por programas nacionalistas e modernistas, em perspectiva de fusão, ou de amálgama, do supra-regional". Antelo cita, entre outras revistas, a Travel in Brazil, que "assinala um aspecto mais instigante da modernidade periférica: seu inconsciente ótico." 
Hoje esquecida em acervos de bibliotecas públicas, a Travel in Brazil 2, na esteira do Modernismo estético, procurava amalgamar tradição e modernidade, sobrepondo o nacional ao regional. Não estava dela ausente a "antropofagização" do estrangeiro, pois contava tanto com a contribuição de fotógrafos europeus, que registravam aspectos das grandes cidades e de rincões do Brasil profundo, como também de autores estrangeiros que relatavam experiências de viagem pelo país. Ao instrumentalizar o "olhar estrangeiro", corroboravam-se as imagens que o Brasil desejava projetar de si para o exterior.

\section{2. "Um Coronel muito estranho": estilo, intertextu- alidades, lendas, fotografias}

No artigo "Um Coronel muito estranho", Florência introduz Santo Antônio por meio de metonímias, que é um procedimento estilístico comum em textos de prosa de viagem de Cecília Meireles. A autora cria certo enigma, atraindo o leitor para que preencha as indeterminações do texto, introduzidas por meio de referências aos locais de nascimento e morte do santo, ordem religiosa em que ingressou, proteções a ele atribuídas e lendas relacionadas a sua vida. É com essa mesma estratégia que Meireles introduz o poeta Gonzaga em "A Casa e a Estrela", de 1953 [1999], como se pode ler a seguir:

Enquanto o mundo está passando por um horrível tempo de guerra, e cada nação tem uma história militar mais notável para contar, eu acho que não vai ser inútil relacionar isso a um coronel brasileiro muito estranho.

$\mathrm{Na}$ verdade, esse soldado não era um cidadão brasileiro. Ele nasceu em Lisboa, em 1195, e morreu em Pádua, Itália, no ano de 1231. É um soldado muito antigo, como vocês podem ver, de cerca de quatro séculos antes da descoberta do Brasil.

Embora seu nome cristão tenha sido Fernando, ele é mais conhecido por Antônio, que adotou quando, com 25 anos de idade, entrou para a Ordem de São Francisco. Esse estranho coronel era um monge também - você pode imaginar? ("Um Coronel muito estranho", 1941, p. 26)

2 Durante o desenvolvimento de projetos de pesquisa, financiados pelo CNPq, foram localizados exemplares da revista Travel in Brazil nas bibliotecas do IEB-USP e Nacional do Rio de Janeiro. 
Para onde vou, que o dia se me afigura tão leve, e a paisagem mais bela que nunca? Ao encontro de quem vou, para que meu coração se adapte a um novo ritmo, e o mundo, dentro de mim, seja, mais do que nunca, um forte contraste de amargura e alegria?

$[\ldots]$

Ah, porque eu venho visitar uma sombra. Um fantasma, que, se fosse vivo, teria mais de duzentos anos.

$[\ldots]$

Venho visitar "um triste pastor". Um triste pastor arcádico. De outros campos. De outras ovelhas. Com os olhos perdidos por lugares muito estranhos, e a vida despedaçada, por forças sobrenaturais. ("A Casa e a Estrela", 1999, p. 179-180)

Ambos os textos revelam uma inquietação por meio de expressões antitéticas. Em "Um Coronel muito estranho", a partir da oposição entre “tempos de guerra” X “Coronel santo", Meireles se propõe a apresentar ao leitor estrangeiro uma lenda religiosa que remete à História de Portugal e à do Brasil: a existência de um santo que era também militar. Como o texto é publicado durante a II Guerra Mundial, pode-se pensar que em oposição a esse pano de fundo, o santo evocaria a autoimagem de cordialidade do brasileiro: aqui os santos participam das guerras, se humanizam, o que coloca o país sob sua proteção. A primeira edição de Raízes do Brasil, de Sérgio Buarque de Holanda, que também foi colaborador da Travel in Brazil, é de 1936.

Em "A Casa e a Estrela", Meireles relata um deslocamento espacial configurado como paisagem bela (alegria) X novo ritmo (amargura). Nessa crônica, ela registra uma experiência de viagem em que se revela uma tensão subjetiva, afetada, ao mesmo tempo, de amargura e alegria. Viaja motivada por encontrar alguém, mas desejando permanecer em seu ponto de partida, como o leitor irá saber: o alguém está nas cercanias do Porto, mas a beleza, ela reconhece em Lisboa, de onde parte sem querer partir. Já no texto da Travel in Brazil, a antítese está objetivada: trata-se de um santo que é também militar, partindo dessa oposição busca-se afetar a subjetividade do potencial leitor-turista ao aludir à ideia de proteção e ao caráter cordial.

O Coronel Estranho e a sombra/fantasma são muito antigos: o primeiro teria mais de setecentos anos, o segundo, mais de duzentos. Os 
dois textos são permeados pela marca estilística das interrogações, mas enquanto aquele que é destinado ao olhar turístico projeta as interrogações para o leitor ("você pode imaginar?"); a crônica originada de uma experiência de viagem introjeta a interrogação, é a autora que pergunta a si mesma por que sai de Lisboa - de que tanto gosta - para viajar ao Porto - em busca de vestígios do "fantasma".

Ambos os textos supõem um leitor competente para preencher seus pontos de indeterminação e decifrar as personagens que evocam. "Um Coronel muito estranho": nasceu em Lisboa, morreu em Pádua, entrou para a Ordem de São Francisco, adotou o nome de Antônio, é coronel e monge. "A Casa e a Estrela": "triste pastor arcádico", "de olhos perdidos por lugares muito estranhos", "vida despedaçada", "forças sobrenaturais". Cecília Meireles completa o jogo de preenchimentos, nomeando, em um caso, Santo Antônio, e noutro, o poeta Tomás Antônio Gonzaga:

O dia 13 de junho é a data de sua morte, abrindo as festas concernentes a alguns importantes santos católicos, em Portugal e no Brasil, incluindo os apóstolos Pedro e Paulo. Essas festividades em ambos os países consistem em fogueiras, balões de papel colorido, fogos de artifício, e a adivinhação do destino através de vários truques especiais de mágica.

Entre João, o Batista, Pedro e Paulo, está o amigável português Santo Antônio. A razão não é apenas explicada, talvez, por seus esplêndidos apelidos: "Chave de Ouro", "Luz da Igreja", "Defensor da Fé", "Casa dos Milagres", mas, porque o santo é considerado o protetor das donzelas e o melhor casamenteiro na terra e no céu! ("Um Coronel muito estranho", 1941, p. 26)

E eis-me aqui, mais de duzentos anos depois do nascimento dessa criança, a contemplar a sua casa como se fosse a de um parente querido. Quem diria, Gonzaga, que nascias aqui, mas era ao Brasil que pertencerias? (“A Casa e a Estrela", 1999, p. 183)

Os textos revelam um mesmo estilo de escrita, em que o jogo metonímico é, por fim, esclarecido a partir da nomeação direta das personagens: o santo e o poeta, o que pode corroborar a hipótese de que Florência é pseudônimo de Meireles. Aproximados pelos procedimentos estilísticos e pelo tema da viagem, revelam propósitos e leitores potenciais distintos. Em "Um Coronel muito estranho", o objetivo é apresentar as festas juninas e o Convento de Santo Antônio a um possível turista norte-americano. Em "A Casa e a Estrela", a finalidade é o próprio texto, enquanto materialização de 
uma experiência lírica de viagem: vivenciado o prazer, algo melancólico, de um deslocamento até o local onde está situada a casa em que nasceu o poeta Gonzaga, nas proximidades do Porto, Cecília Meireles faz dessa viagem um registro em prosa-lírica, que deseja compartilhar com o leitor.

Meireles (1941, p. 26), na intenção de mostrar curiosidades sobre as lendas que envolvem Santo Antônio ao possível turista norte-americano - que talvez o desconhecesse -, aproxima-se desse leitor, por meio de referências diretas a ele: há o uso do pronome "você", explicitado no texto, além de interrogações diretas e exclamações. Dialoga com o leitor e, em tom de confidência, liga a vida do santo à lenda da linda moça judia que o seduz, mas que revela ser o diabo transfigurado:

Sua vida esquisita é cheia de outras coisas inesperadas. Quando ele ainda era um simples menino do coral, o que você imagina que aconteceu? Oh! Sinto muito, mas diz-se que ele se apaixonou por uma moça judia extremamente linda! Não culpe o garoto ousado! Assim que essa paixão violenta incomodou seu coração, a Graça Divina o iluminou, ele fez o sinal da cruz e a bela garota desapareceu, pois ela não era nada, além do próprio diabo sob disfarce feminino.

Nesse trecho podem ser encontradas relações intertextuais com lendas que associavam semitas a transfigurações diabólicas, comuns na tradição popular da Península Ibérica, como aparece no conto "A Dama Pé de Cabra", escrito por Alexandre Herculano, a partir de narrativas orais. Embora a Dama Pé-de-Cabra não fosse propriamente judia ou muçulmana, é sobre a relação de pertencimento a esses povos a primeira associação que D. Diogo Lopes faz quando a bela mulher aparece e lhe exige abdicar da devoção cristã. Também Rosaflor e a Moura Torta se passa na Espanha na época do domínio árabe. Gilberto Freyre (2016, p. 71), em Casa-Grande \& Senzala, trata do imaginário sobre a mulher semita transposto pelos ibéricos para o Brasil que se cinde em duas visões antagônicas: a moura encantada e a moura torta. Vale lembrar que o artigo foi publicado em 1941, no contexto das perseguições aos judeus durante a II Guerra Mundial. No Brasil, Vargas editava decretos que dificultavam a entrada de refugiados judeus. Nesse contexto, a lenda em torno da paixão de juventude de Santo Antônio contribui para reforçar estereótipos ligados aos povos semitas na cultura ocidental.

Meireles informa também que Antônio era um pregador capaz de agitar emocionalmente as pessoas com seus apelos religiosos. Depois introduz as festas juninas, uma delas dedicada a Santo Antônio, em 13 de junho, 
supostamente o dia de sua morte. $\mathrm{O}$ ardor religioso entre brasileiros - como também assim existe em Portugal - se traduziria em alegre festividade. Meireles apresenta dois epítetos que se amalgamaram à figura de Santo Antônio: casamenteiro, de devoção das moças, e protetor dos soldados.

Em seguida, conta a história militar de Santo Antônio, que teria se iniciado em meados do século XVII, quando é alistado pelo rei português como protetor dos soldados. No fim do século XVII é promovido a capitão. No século XVIII, torna-se capitão também no Brasil, na luta contra os franceses no Rio de Janeiro, e pela primeira vez aparece o nome da personagem como sendo Santo Antônio. Conforme Meireles (1941, p. 27), a história do santo militar prossegue no Brasil até o início da segunda década do século XX:

O Rio de Janeiro já tinha uma igreja consagrada ao santo, que possuía um rico bastão. Esse bastão foi enviado pelos Franciscanos para o governador da cidade, que encabeçava suas tropas. Diz-se que o governador só tocou sua cabeça com a parte superior da maravilhosa cana e a enviou de volta à igreja, mas pediu aos frades para colocarem a estátua do santo na parte superior da parede maciça do mosteiro. E a partir deste lugar o santo poderia observar, como um general, a derrota francesa.

No ano de 1814, Santo Antônio foi elevado ao posto de coronel. Poucos dias antes, ele havia recebido do príncipe D. João a insígnia da Ordem de Cristo. O mesmo príncipe deu-lhe outro bastão, mais precioso que aquele com o qual o governador tocou sua cabeça, no dia do ataque francês.

A República não modificou o estatuto do santo. Foi ordenado que o pagamento do salário continuasse e assim foi até o século $\mathrm{XX}$.

Cecília Meireles (1941, p. 27) conclui seu artigo em tom de conversa com o leitor, lembrando-o de que a igreja dedicada ao santo é um dos templos religiosos mais bonitos do Rio de Janeiro, e aludindo à cordialidade brasileira, pois aqui o santo é casamenteiro, festeiro e protetor da pólis, pode agir com afeição ou com a agressividade protetora de um patriarca, conforme seu coração manda...

O mosteiro de Santo Antônio é um dos mais bonitos prédios religiosos do Rio de Janeiro. É o santo que as moças adoram, - o velho defensor da cidade, que de fato foi fundada sob a proteção de outro santo, São 
Sebastião. Mas, vocês imaginam? Os santos são melhores do que os homens para compreenderem o verdadeiro sentido de cooperação.

E agora, nesta época de canhões e batalhas aéreas, você pode perceber a importância de ter um santo à frente do Exército? Grande é o poder humano, mas é sempre aumentado por um pouco de força Divina.

No site do Convento de Santo Antônio constam informações sobre a primeira imagem desse santo que esteve no Convento a ele dedicado, e que hoje está na fachada do edifício. Há referências às funções do santo como protetor militar, informações técnicas sobre o material e a forma da escultura. Há também um relato sobre a lenda em torno da confecção da imagem:

A primeira imagem de Santo Antônio que esteve no retábulo maior encontra-se hoje no frontispício do convento. Sobre ela existe a lenda de que, tendo um frade esculpido o corpo, não conseguia acertar a cabeça, que teria sido esculpida por um pedinte, em poucos minutos, enquanto o Frade fora buscar para ele um prato de comida.

O fato é que a cabeça é separada do corpo. Foi esta a estátua que presidiu o exército na expulsão dos franceses em 1710. Em gratidão do povo, ela foi parar no frontispício da igreja e recebeu uma lâmpada votiva até hoje acesa. Todos os anos o Menino recebe uma veste nova.

Foi esta estátua do Santo que foi condecorada várias vezes pelas autoridades e recebeu soldo do exército até 1911. Ela é de terracota. A atual imagem do altar-mor, também de barro cozido, bem maior que a primeira, mostra o Santo descalço, sustentando o livro, o Menino, a cruz e o galho de lírios. Ela deve ter sido posta lá entre 1707 e 1710. (<http//www.conventosantoantonio.org.br/>, Acesso em: 24/05/2019.)

Cecília Meireles não desconhecia a lenda da confecção da imagem do santo, em que o corpo foi manufaturado separado da cabeça, sendo as partes atribuídas a escultores populares diferentes, mas não a insere no texto para a Travel in Brazil. Talvez por não a ter considerado digna de interesse turístico. Assim ela relata essa lenda no livro Artes Populares (1952, p. 34):

Da mesma espécie é a notícia de Pizarro sobre a imagem de Santo Antônio, baseada em "escritos antigos de pessoas dignas de fé" e confirmada pela "tradição constante". Segundo o cronista, um religioso capucho formou o corpo do Santo, mas nunca lhe conseguiu ajustar as 
cabeças que fizera, por serem todas maiores ou menores para a imagem. Uma noite, bateu a sineta da portaria, e, quando atenderam, encontraram a "cabeça do santo que levada com grande admiração dos religiosos perfeitamente se uniu ao corpo, como obra fabricada por mãos sobrenaturais".

Esse relato guarda diferenças em relação ao que consta no site do Convento, pois enquanto este acentua a compaixão dos religiosos para com os pobres como explicação para a confecção da cabeça do santo, no relato de Cecília Meireles, atribuído a um viajante, acentua-se o aspecto sobrenatural da união entre cabeça e corpo.

No que diz respeito às ilustrações, "Um Coronel muito estranho" conta com duas fotografias. Na primeira página, há uma foto frontal da imagem de Santo Antônio segurando o Menino Jesus, com a cruz e o bordão. É um close do nicho, que fica sobre o portal da igreja, onde está posta a imagem desde o início do século XVIII, quando ocorreu a luta contra os franceses. Na segunda página, há uma foto que revela uma visão lateral do frontispício da igreja, tirada em posição levemente inclinada, de baixo para cima. No centro, vê-se o nicho que abriga a imagem de Santo Antônio no alto da igreja. No plano inferior, vêem-se dois padres que descem as escadarias em direção à rua. Destaca-se assim os planos divino, no alto da igreja onde reside o santo, e terreno, alusivo à missão dos religiosos nas ruas da pólis. Ambas as fotografias são creditadas ao alemão Paul Stille.

No plano técnico, a própria materialidade da revista, que associa texto e fotografia, sugere a modernidade brasileira sob o Estado Novo. No plano temático, "Um Coronel muito estranho" aproxima as tradições religiosas do Brasil às de Portugal, enfatizando as origens europeias, como pretendia a ideologia de Vargas. A civilidade brasileira está acentuada no patrimônio histórico e artístico que o Convento de Santo Antônio representa e em suas potencialidades para atrair o olhar turístico.

\section{3. "Penha": estilo, lendas, fotografias}

A análise literária do artigo "Penha", assinado por Florência, será iniciada a partir de comparação com a crônica de Cecília Meireles, "Voz em Florença", de 1953 [1999], a fim de verificar semelhanças estilísticas:

No caminho do Rio de Janeiro a Petrópolis, passando por um dos subúrbios, pode-se ver uma pequena igreja graciosa, pousada no topo de uma rocha, solitária na planície. A rocha é de cerca de 300 pés de altura 
e o culto lá existente originou-se por volta do ano 1635. ("Penha", 1942, p. 28)

A primeira coisa que avisto é Santa Maria Novella, - o que me faz retroceder seis séculos, e encontrar as sete jovens senhoras que, num canto dessa igreja, se propunham a abandonar a cidade invadida pela peste, e às quais Boccacio iria atribuir as famosas histórias do seu "Decameron". ("Voz em Florença", 1999 [1953], p. 75)

Ambos iniciam pela apresentação de uma igreja. Nossa Senhora da Penha, visível no caminho do Rio de Janeiro a Petrópolis, por estar situada no alto de uma rocha. Santa Maria Novella, facilmente avistada ao se chegar a Florença pela estação de trem homônima, devido à sua monumentalidade. Depois, são introduzidas lendas vinculadas a cada uma das igrejas: o culto que se originou na Penha deve-se ao devoto que teria recebido a graça da Virgem; a igreja florentina liga-se às moças ali refugiadas, que seriam as narradoras do Decameron, de Boccacio. À igreja carioca, vincula-se a narrativa oral de um milagre, cuja cena os devotos representam em suas medalhas. À igreja florentina, vinculam-se supostas narrativas orais registradas literariamente por Boccacio. As narrativas ligadas às igrejas são muito antigas: a carioca remonta ao início do século XVII; a florentina, ao século XIII.

Após contar a lenda do milagre, a autora (1942, p. 28) chega ao objetivo do texto, que é tornar objetos do olhar turístico a romaria em devoção a Nossa Senhora da Penha e a quermesse a ela vinculada:

Não há festa religiosa mais popular no Rio de Janeiro do que a Nossa "Senhora da Penha". Ela continua durante todo o mês de outubro, e todos os domingos do mês, hordas de peregrinos vão à igreja para cumprir votos feitos, e para aproveitar a oportunidade de dançar, cantar, fazer piquenique e participar de sorteios nos amplos jardins que rodeiam a igreja.

Em "Voz em Florença", Cecília Meireles mostra a cidade sob filtro intertextual com a Divina Comédia, pois a voz que acompanha a viajante em sua passagem por Florença será, aos poucos, revelada como sendo a de Dante Alighieri, que Meireles (1999, p. 78) introduz a partir de uma comparação com a rigidez "eterna" das torres da igreja: "E nada me lembra tão vivamente Dante como estas torres de pedra, que vencem o seu próprio peso e se empurram a si mesmas para o céu, conhecendo as profundidades dos abismos inferiores por onde passaram". 
Em "Penha", o foco é acompanhar a devoção e os festejos populares para apresentá-los ao estrangeiro e deles fazer objeto do olhar turístico, vinculando-os à lenda da intervenção milagrosa da Virgem. Em "Voz em Florença", o foco da cronista é registrar a própria experiência da viagem a Florença, filtrada por memórias literárias. A atração turística pela igreja carioca vincula-se a narrativas orais. A atração por Florença, a determinados marcadores literários ${ }^{3}$ ligados a Dante e Boccacio, e a visita a esses lugares torna-se a motivação da viagem, constituindo-se no que hoje nomeia-se turismo literário. As semelhanças estilísticas permitem afirmar que Florência é um pseudônimo de Cecília Meireles.

Em "Penha", Meireles (1942, p. 28-29) explica as origens do culto à santa, que teve início por volta de 1635 :

Essa igreja pitoresca possui uma lenda poética: Em meados do século XVII, um viajante cansado deitou-se para descansar perto da base da rocha. Ao adormecer, sonhou que um crocodilo gigante, com más intenções, estava rastejando sobre ele; ele estava apavorado demais para se mover, e olhando em volta, ele viu uma Santa sorridente flutuando em uma nuvem de neve próxima.

Ele acordou de repente, e descobriu, para seu horror, que havia realmente um crocodilo rastejando em direção a ele; paralisado de medo, ainda permaneceu imóvel e, em seguida, viu uma grande serpente aparecer, que, deslizando até o crocodilo, enterrou suas presas venenosas no pescoço do réptil, a serpente, em seguida, deslizou para longe da pedra, desaparecendo da vista do homem.

Ele, então milagrosamente salvo, levantou-se e seguiu o rastro da serpente ao pé da rocha, e, olhando para o lado nu dela, viu uma nuvem branca que descansava na parte superior. Ele imediatamente recordou a Santa de seu sonho, e pensou sobre alguma forma de mostrar sua gratidão pela ajuda que havia recebido. Só então, um coelho branco saiu dos arbustos, e pulou lentamente até a rocha, parando com frequência e, olhando para o homem, como se o convidando a acompanhá-lo até a rocha; o viajante seguiu o coelho para o topo da rocha, e lá encontrou uma imagem da Santa que lhe tinha amizade.

3 Para Quinteiro e Baleiro (2017, p. 53-54), a referência literária que o leitor "arrasta" para o espaço geográfico, durante sua viagem turística, chama-se "marcador". Sendo o "lugar literário" uma fração de espaço físico na qual o turista-leitor reconhece o marcador literário. 
No site da Basílica de Nossa Senhora da Penha, constam as seguintes informações sobre o suposto milagre que teria dado origem à construção da igreja:

[...] Tudo começou no início do século XVII, por volta do ano de 1635, quando o Capitão Baltazar de Abreu Cardoso ia subindo o Penhasco (grande pedra) para ver as suas plantações, uma vez que era proprietário de toda a área no entorno do atual Santuário. De repente foi atacado por uma enorme serpente. Baltazar, que era devoto de Nossa Senhora, quando se viu só e incapaz de se defender, pediu socorro a Nossa Senhora gritando: "Minha Nossa Senhora, valei-me!". Nesse preciso momento surgiu um lagarto inimigo das serpentes, e travou-se uma luta mortífera entre os dois animais. Baltazar por sua vez, não perdeu tempo e fugiu.

Depois de se recuperar do susto, Baltazar reconheceu que o lagarto apareceu precisamente no momento em que ele pediu a proteção da Virgem Maria. Agradecido, por tão importante gesto maternal, Baltazar construiu uma pequena capela onde pôs uma imagem de Nossa Senhora. Se antes o Capitão Baltazar subia o penhasco para ver as suas plantações, a partir daí passou a subir também para agradecer tão primoroso gesto de carinho que a Mãe do Céu teve para com ele. Assim como ele, também os seus parentes, amigos e vizinhos e até mesmo pessoas curiosas, que à distância viam a pequena capela, passaram a subir a grande pedra (daí vem a palavra Penha) uns para pedir e outros para agradecer graças alcançadas por intercessão da Senhora do alto do Penhasco - Penha. (<http://www.basilicasantuariopenhario.org.br/>, Acesso em: 24/05/2019.)

Nesse relato não há menção ao viajante, trata-se de um fazendeiro, que, ao visitar suas plantações, é surpreendido por uma cobra. Não há referências à aparição da Virgem em sonho, mas Baltazar, assustado, invoca a proteção da santa, que envia o lagarto para salvá-lo. Não há coelho branco que guia o viajante até o alto da rocha, onde encontra a imagem da Virgem. O relato registrado no site da Basílica é mais "realista", limpo de elementos maravilhosos: simplesmente o fazendeiro decide construir o santuário no alto da rocha para prestar devoção à santa a quem atribui sua salvação milagrosa do ataque da cobra. Com a construção do santuário surge a peregrinação ao alto da Penha, a fim de pedir graças ou pagar promessas por graças alcançadas.

A estampa, que narra pictoricamente o milagre, é a ilustração que abre o artigo "Penha", da Travel in Brazil, em fotografia de Jean Man- 
zon. Vê-se, no canto inferior direito, um homem ajoelhado, em devoção à santa, cuja representação é central e ocupa metade da estampa. Ela está elevada ao céu, sobre uma nuvem, e segura o Menino Jesus, ambos coroados. Um pouco abaixo da santa, do lado esquerdo do espectador, está a igreja. A serpente olha para o homem ajoelhado, pronta para dar o bote, enquanto o jacaré aproxima-se pela lateral esquerda, abaixo da representação da igreja. A estampa corrobora a versão de que o homem teria sido salvo pelo jacaré enviado pela Virgem.

O artigo destinado à Travel in Brazil apresenta elementos que operam no eixo familiarização-desfamiliarização. A figura do viajante, a quem a graça é concedida, parece aproximar a personagem do leitor pretendido. A inserção de elementos maravilhosos, ausentes do relato que está no site da Basílica, parece pretender associar a igreja a relatos maravilhosos orais e à obra de Lewis Carroll, Alice, no País das Maravilhas, de que Cecília Meireles tanto gostava. Afinal, de onde ela teria sacado o "coelho branco" para conduzir o viajante ao alto da rocha?! O viajante está adormecido - como Alice - , vê em sonho o crocodilo pronto a atacá-lo e a santa que intervém para salvá-lo. Não há crocodilos no Brasil, somente jacarés, e o mais comum é que o jacaré seja predador da serpente e não o inverso. Talvez, pensasse a escritora, que essa inversão e o acréscimo de elementos maravilhosos, literariamente inspirados, fossem capazes de evocar maior grau de aventura para o turista.

Após o relato do milagre, Meireles introduz a festa popular que se originou em torno da romaria, que ocorre em todos os domingos do mês de outubro. Informa que o acesso ao santuário se faz por meio de uma escadaria de 365 degraus:

Para alcançar o Santuário, situado no topo da rocha, é preciso subir 365 degraus, cortados na rocha sólida. Uma das promessas mais populares para a Santa Padroeira, é que se o pedido desejado for concedido, o beneficiário vai subir todos os 365 degraus até o altar, de joelhos; e numerosos são os devotos de "Nossa Senhora da Penha" que sobem ao altar, a pé e de joelhos, os degraus já estão muito desgastados, e muitos já foram reconstruídas com cimento. (MEIRELES, 1942, p. 30)

No site da Basílica de Nossa Senhora da Penha pode-se ler as seguintes informações a respeito das escadarias:

No ano de 1817 subia a pedra um piedoso casal quando a esposa, Sra. Maria Barbosa, comentou com o marido que pediria à Nossa Senhora 
da Penha para interceder por eles para que Deus lhes concedesse um filho, já que estavam casados há alguns anos e não tinham filhos.

A Sra. Maria Barbosa confiou, pediu e prometeu que se tivesse um filho mandaria esculpir no duro granito do penhasco uma escadaria para facilitar o acesso dos devotos de Nossa Senhora da Penha ao Santuário. No ano seguinte o casal era presenteado com um lindo filho e no ano de 1819 a escadaria estava pronta. São 382 degraus talhados na própria pedra, mais ainda do que o número de dias do ano. (<http://www.basilicasantuariopenhario.org.br/>, Acesso em: 24/05/2019.)

Meireles ressalta a penitência de subir as escadarias de joelho, o que poderia parecer pitoresco ao olhar do turista norte-americano, provocando-lhe curiosidade e desfamiliarização. Informa que são 365 degraus, o que sugere a associação com um ano. Haveria, implicitamente, a ideia de que subir cada degrau corresponderia a salvar do pecado cada dia do ano. Associação esta que evocaria um grau maior de maravilhoso e pitoresco que o do relato que consta no site da Basílica, que diz que são 382 os degraus, "mais ainda do que o número de dias do ano". No site, não há referências à penitência de joelhos, apenas ao milagre que irá dar origem à construção das escadarias, informa o nome da agraciada e a data aproximada: Maria Barbosa, em 1817.

Cecília Meireles parece adaptar as informações na intenção de afetar o turista estrangeiro, pois acrescenta elementos maravilhosos aos relatos em torno da igreja e acentua o pitoresco das penitências, mas provoca certa familiaridade ao atribuir a graça a um viajante e ao modificar o número de degraus para aludir aos dias do ano. Depois, introduz os festejos que ocorrem após a romaria, ao redor da igreja, com música, dança, piquenique, rifas etc.

O texto de Meireles é ilustrado com cinco fotografias, todas creditadas a Manzon. As fotografias ocupam mais da metade das páginas, uma delas, uma página inteira. Como foi mencionado, a primeira fotografia mostra a estampa que narra pictoricamente o milagre que deu origem ao santuário.

A segunda fotografia mostra uma multidão de peregrinos subindo as escadarias. Essa foto é tirada em ângulo inclinado, "de baixo para cima", acentuando a inclinação das escadarias que conduzem ao santuário. Os peregrinos caminham em ambas as direções. Em sua quase totalidade, os homens são brancos ou embranquecidos e vestem ternos, gravatas e cha- 
péus. Um rosto, em meio à multidão, focalizado de frente, na parte inferior, do lado esquerdo do espectador, parece retornar do santuário. Outro homem, ao lado desse, aparece de perfil. Ambos são brancos, cabelos alinhados, vestem ternos claros. Produz-se um duplo efeito: a familiarização e a desfamiliarização que a atividade turística organizada deve provocar. A aparência dos peregrinos lembra a de um homem norte-americano ou europeu - o que reforça relações de proximidade com o país a visitar -, mas a atividade religiosa, que associa devoção e diversão - incomum a um mundo predominantemente pragmático e puritano - poderá provocar a curiosidade turística.

A terceira foto apresenta a multidão de pessoas ao redor da igreja durante a quermesse (a legenda informa que "no pátio da igreja há música, danças, rifas, piqueniques etc"). Em seguida, talvez com o propósito de reforçar a diversão após a romaria e aproximar o leitor, vê-se, na quarta foto, uma roda gigante, com muitas pessoas ao redor, ocupando uma página inteira.

A última fotografia apresenta uma menina de costas, vestida de anjo, subindo as escadarias da Penha, acentua-se aqui o movimento, sugerido pelas asas postiças presas aos ombros da menina. Essa foto também é tirada de baixo para cima, mostra não uma pessoa em posição frontal, mas de costas, o que pode contribuir para ressaltar o duplo efeito de familiarização - perceptível na modernidade da revista ilustrada, no ângulo incomum e no fato de a jovem ser branca, de pele e cabelos claros, levemente ondulados - e a inofensiva desfamiliarização turística, provocada pelo traje e pela romaria. O ângulo artístico coloca a jovem simetricamente entre dois homens brancos, ambos sobem as escadarias, estão de costas, usam chapéus e ternos, o do lado esquerdo da jovem veste terno escuro; o do lado direito, terno claro. A foto é de grande leveza e simetricamente harmônica.

As cinco fotos compõem um conjunto narrativo, que acompanha o texto ceciliano: estampa que remete à lenda que deu origem ao santuário; os peregrinos em duplo movimento de subida e descida, sugerindo a perpetuação da fé católica; devoção essa que não é avessa aos prazeres carnais, como se pode verificar nas fotos da quermesse e da roda gigante; e o ciclo se fecha com a salvação, sugerida pela menina-anjo que sobe as escadarias, como um anjo da guarda a seguir os peregrinos. 


\section{Considerações Finais}

A fotografia da menina-anjo durante a romaria da Penha sugere a "exigência de ser lembrado" que o sujeito fotografado impõe ao espectador, como considera Agamben (2007, p. 28-29):

Mesmo que a pessoa fotografada fosse hoje completamente esquecida, mesmo que seu nome fosse apagado para sempre da memória dos homens, mesmo assim, apesar disso - ou melhor, precisamente por isso - aquela pessoa, aquele rosto exige o seu nome, exige que não sejam esquecidos.

A menina-anjo não mostra um rosto individualizado, mas por elidir o rosto, a fotografia promove o reconhecimento, inspirado no maravilhoso católico, do ciclo da vida que ela evoca. Mas, na riqueza do material fotográfico que ilustra a Travel in Brazil, muitos rostos se mostram e parecem também exigir o não esquecimento. Nos artigos aqui analisados: romeiros e padres católicos saindo da igreja para a cidade. Na variedade temática de outros artigos que compõem as revistas: pessoas fotografadas em cafés, em livrarias, nas ruas, divertindo-se no carnaval carioca, vaqueiros em montaria no interior do Brasil, vendedores ambulantes, pescadores... Mosaico de um país que amalgama urbanidade, tradições populares e regionais que a revista pretendeu divulgar para um Outro mais poderoso, sob uma ótica que a aproxima do Modernismo estético.

\section{REFERÊNCIAS BIBLIOGRÁFICAS}

AGAMBEN, Giorgio. Profanações. Tradução de Selvino J. Assmann. São Paulo: Editorial Boitempo, 2007.

ANTELO, Raúl. Potências da Imagem. Chapecó: Argos, 2004.

BASÍLICA Nossa Senhora da Penha. Disponível em: <http:/www.basilicasantuariopenhario.org.br/>, Acesso em: 24/05/2019.

CONVENTO de Santo Antônio. Disponível em: $<$ http//www.conventosantoantonio.org.br/>, Acesso em: 24/05/2019.

FREYRE, Gilberto. Casa-Grande \& Senzala. São Paulo: Global, 2016. 
GRIECO, Bettina Zellner (Org.). Entrevista com Erich Joachim Hess. Rio de Janeiro: IPHAN, 2013.

Erich Hess: Fotografia e Patrimônio. Belo Horizonte: Forum Patrimônio, vol. 9, nº 1, jan.-jun. de 2016.

HOLANDA, Sérgio Buarque de. Raízes do Brasil. 18.ed. Rio de Janeiro: José Olympio Editora, 1984.

LACERDA, Aline Lopes. “A ‘Obra Getuliana' ou como as imagens comemoram o regime”. Estudos Históricos. Vol. 07, N. 14. Rio de Janeiro, 1994.

LISSOVSKY, Maurício. "Brasil, Refúgio do Olhar: Trajetória de um fotógrafo exilado no Rio de Janeiro dos anos 1940". Revista Brasileira de História da Mídia. Vol. 2, N² 2. Universidade Federal do Piauí, 2013.

MEIRELES, Cecília. "Um Coronel muito estranho". In: Travel in Brazil. Rio de Janeiro: The Press and Propagand Dept. Vol. 1, N. 2, 1941, p. 26-27.

. "Penha". In: Travel in Brazil. Rio de Janeiro: The Press and Propagand Dept. Vol. 2, N. 2, 1942, p. 28-32.

. Artes Populares. Rio de Janeiro: Ediouro, 1952.

. Crônicas de Viagem 2. Rio de Janeiro: Nova Fronteira, 1999.

QUINTEIRO, Ślvia e BALEIRO, Rita. Estudos em Literatura e Turismo:

Conceitos Fundamentais. Lisboa: Universidade de Lisboa, 2017.

Recebido em: 31/07/2019

Aceito em: 07/01/2020 